\title{
DAVID THE INVINCIBLE: PHILOSOPHY AS A LIFESTYLE
}

\begin{abstract}
The most outstanding representative of the history of Armenian philosophy, Neoplatonic thinker of the V-VI centuries, David the Invincible continues the tradition reached the peak of its development in the Ancient Greece by Socrates and Plato, according to which philosophy is first of all a way of life, a means of transformation and perfection of the human being. Following the principles of the Greek Paideia David considers philosophy as a care of the soul, in which theory and practice are intertwined, and cognition of the world depends on the efforts of self-improvement by a subject. Author shows that in David's definitions of philosophy is clearly seen the significance of selfformation, "zardarum" in the process of reality formation, comprehension or rethinking. It is also mentioned that we can use Michel Foucault's notion of the "care of the soul" and Pierre Hadot's notion of "spiritual practices" to characterize David's optimistic philosophy, which was developed further in the theories of Armenian thinkers Grigor Narekatsi, Grigor Magistros, Hovhannes Imastaser, Arakel Sjunetsi, etc.
\end{abstract}

Keywords: David the Invincible, Socrates and Plato, Paideia, care of the soul, spiritual practices, Foucault, Hadot.

David the Invincible, Armenian great Neo-Platonist philosopher of V-VI centuries, continues the tradition that reached the peak of its development in the Ancient Greece by Socrates and Plato, according to which philosophy is first of all a way of life, a means of transformation and perfection of the human being. Following the principles of the Greek Paideia David considers philosophy as a care of the soul, in which theory and practice are intertwined, and cognition of the world depends on the efforts of self-improvement by a subject. His epithet "Invincible", according to Armenian tradition, David earned winning in philosophical debates with representatives of Hellenistic philosophy of the time. David is also known as one of the most outstanding figures in Armenian intellectual history. His influence was so great that, as a rule, every Armenian thinker attempting to make judgments in the field of philosophy, started with the interpretation of David's main works. Nevertheless, his life, activities, and his philosophical writings are not fully investigated yet and there are many uncertainties and questions concerning his personality and philosophical heritage.

David the Invincible acted in the era called Golden Age of Armenian literature. That was an era generated by adoption of Christianity as a state religion of Armenia in the beginning of the $4^{\text {th }}$ century and by crea- 
tion of Armenian alphabet by St. Mesrop Mashtots in the beginning of the $5^{\text {th }}$ century. Armenian intellectual, literary and artistic life was developed simultaneously with establishment of Philhellene school which translated many ancient texts on grammar, rhetoric, and especially classical Greek philosophy. Works of Plato, Aristotle, Philo, Porphyry, Dionysus of Thrace, Theon of Alexandria and others were rendered. The translations as well as the original works of the Philhellene scholars laid the foundations for the secular sciences in Armenia and paved the way for David Anhaght's (Invincible's) unique contributions to the development of Armenian Philosophy (Sanjian, 1986, p. 2).

David's survived heritage contains of four works that are texts of his lectures wrote down by his students. Greek texts of David are published in Commentaria in Aristotelem Graeca (CAG), vol. XVIII, part 2 (Busse, 1904), and one work, "The Interpretation of Aristotle's Analytics", has survived only in its Armenian version (David the Invincible, $1980^{\mathrm{a}, \mathrm{b}}$ ).

In his works David states that "Human being is a rational, mortal creature, able to think and learn", and salvation of the human being, according to David, is connected with rational activities of humans, as we can see in his texts (David the Invincible, 1980a, b). David the Invincible was elevated to the rank of saints by Armenian Apostolic Church. The date and circumstances of the conferral of sainthood upon David are unknown. But we can state, however, that among the numerous ancient Armenian authors only Eghishe, Movses Khorenatsi and David the Invincible have been canonized. The first two were historians, who wrote the History of Armenian nation in the light of Christianity, and developed Armenian Christian Identity; and only David was a philosopher whose survived works are secular by their nature. For many researchers his canonization implies that he must have made a significant contribution to the Armenian Church and maybe he authored other important works of a religious nature as well. We also know that at an advanced age, when David was already well-known and accepted philosopher in the Alexandria and Greek-speaking world, he returned to his homeland, Armenia, and devoted himself to teaching philosophy. But he was met with displeasure and even opposition: his independent thinking and belief in human abilities maybe contradicted with the dominant doctrine of the time. Medieval Armenian sources indicate that David "suffering many tribulations, deprivations and persecution at the hands of his fellow-countrymen" was compelled to take refuge in the northernmost part of Armenia, near the Georgian border (Sjunetsi, 1797). David took refuge and later died in the monastery of Haghbat. His remains were subsequently removed to his native Taron and interred in the monastery of Surb Arakelots at Mush. Of course, it was after his canonization (Muradyan, 1981).

The reason that David's works were read and reread many times by intellectual Armenians since the $6^{\text {th }}$ century till our days is that he developed a theory of humanity, anthropological philosophy which is helping a person to become stronger and more powerful against uncertainty of circumstances. David considered philosophy as a lifestyle, as an ongoing work of soul on its self perfection, and became a teacher for many generations of Armenian thinkers as the challenges of the 
Armenian reality demanded a culture of internal work, of self-improvement and cultivation of soul.

David solved the problem of human being considering philosophy as the care of the soul. This tradition is beginning from Hilo's and Socrates' "Know thyself", and as Michel Foucault mentioned, the demand of selfcognition is based on the demand of the selfcare (epimeleia) (Foucault, 2007). And selfcognition is the private case for the self-care. In its turn the self-care consists of two aspects: the care of the body and the care of the soul. David says that for the care of the body there are different things: hygiene, hairdressing, gymnastics, etc., and for the care of the soul there is philosophy. "And philosophy deals with soul, because it revives and illuminates the soul cleaning its muddy eyes capped with bodily whishes. And now how much the soul is preferable than the body, that much the philosophy, beautifying the soul, is preferable than other arts beautifying the body" (David the Invincible, $1980^{\mathrm{b}}$, p. 124). David belongs to the philosophical tradition of the self care of the soul which was investigated by Michel Foucault who tried to understand the techniques of the self in the Greek-Roman culture. Foucault at the end of his life turned to the classical tradition of philosophizing with the question how ancient thinkers were constructing themselves as subjects. Eventually Foucault concluded that the human being has the moral responsibility towards him/herself in the four aspects: a) there is a material, substance, which is the object of the care; it is the way the person constructs a part of him/herself; b) it is the way by which the individual states his/her relationship towards the law; c) there are means by which the care is "training itself": the person is changing him/herself, transforming as a result of deliberate spiritual exercises to become a moral subject of his/her own behavior; and d) it is the telos, the will to take such a care, which stands as a purpose of personality (Foucault, 1986). The co-author of this approach Pierre Hadot in his works returns to the Plato's notion of the philosophy as an art to live, stating that nowadays there are professors or teachers of philosophy, but not philosophers (Hadot, 1995).

Analogically David states that philosophy is the care of the soul and the most enjoyable and privileged activity for the human being. Philosopher is not the person who merely knows many things, but is the one who lives philosophical life. In his main work, "Definitions and divisions of Philosophy", David represents six definitions of philosophy earned from Greek philosophers: Pythagoras, Plato and Aristotle, choosing these six definitions because of their anthropological orientation. He defines philosophy by the nearest and the most distant subject, by the nearest and the most distant purpose, by priority and as a translation. As a translation "philosophy" is "love of wisdom" - "imastasirutyun" (in Armenian). By priority David defines philosophy as an art of arts and a science of sciences. David stresses this definition many times saying that philosophy is the most important occupation, and other sciences and arts are less important and respectable. Philosophy is the most essential business for a person to make him/herself constant, vise and happy. Philosophy is mother and source for all other sciences and arts according to David. He also compares philosophy with the king: "As king does not directly talk with crowd, but assigns noble men to care for the needs of the neth- 
ermost people, in the same way philosophy puts forward the arts by means of which knows all the things" (David the Invincible, $1980^{\text {b }}$ : 88). But this is not the end, he also compares philosophy with the King of kings the God: "As the God has invisible power to care about mundane creatures, in the same way philosophy puts forward the sciences in order to know their subjects" (David the Invincible, $1980^{\mathrm{b}}$, p. 88).

As every art and every science has a subject and a purpose, philosophy as art of arts and science of sciences also has both a subject and a purpose. And each of these is divided into two categories: a proximate subject and a distant subject; a proximate purpose and a distant purpose. The proximate subject of philosophy is essences as such and distant subjects of philosophy are things or realities: human and divine. So defined by its distant subject philosophy is knowledge of divine and human realities. David says that because philosophy concerns itself with human behavior, it should not ignore the examination of the divine state and that it must follow the examples set by the God. On the basis of what it can learn from the God, it must attempt to elevate human beings to a state of perfection. But for David the theory is practical and the praxis is theoretical, and the knowledge is needed for the right action, which he describes speaking about the proximate and the distant purposes of philosophy. The nearest purpose of philosophy is thinking about the death and the most distant and ultimate purpose of it is becoming like the God to the best of human's ability.

The Invincible understood thinking about the death as the care of the soul and cultivation of virtues; as the death of passions and affects; and cleaning the soul for ability to see the God's light (Petrosyan, 2000). David asserts that the fundamental subject of philosophical concern is comprehension of divine logos. God illuminates everyone, but people who don't have "an eye of soul" can't see this light. The attainment of this objective presupposes liberation from the sinful passions, the "death" or "mortification" of passions. David speaks about "mortification" of passions and negative aspects of the soul. He says that some critics misunderstood Plato's judgment on the death as a desirable thing. They got it in a direct way, but speaking about the death Plato, according to Armenian philosopher, means only cleaning of souls from impurities. To see the daylight we clean our eyes, so for being able to see the God's light we must clean and purify our souls. But a normal person alone is not able to make such changes, $\mathrm{h} /$ she needs help. And philosophers, according to Armenian thinker, are the most perfect human beings who care about souls of other people helping them to find their way to the God. With the help of philosophers the care of soul should become an everyday procedure: we have to clean our souls from different negative emotions, impressions, and resentments. So soul needs cleaning as body does. The hygiene exists for the body's needs and philosophy exists for the soul's needs. In his treatise David twice brings the same citation from Plato's Timaeus 47B to emphasize the importance of philosophy: "Such a thing, Theodorus, has neither been generated by men nor bestowed by God".

The ultimate purpose of philosophy is becoming like to the God. But human being can not be alike the God totally. David says: "We say that the philosopher is like the God 
in the same sense as when we say that Socrates' image is the same as Socrates himself, although Socrates' image and Socrates himself are two different things, because the one is animate and the other is inanimate object. It is in this sense that we say that the philosopher resembles the God, although the God has one essence and the man has another essence" (David the Invincible, $1980^{\mathrm{b}}$, p. 67). David thinks that the God has three characteristics: omnipotence, omniscience and unlimited kindness. The God bears unlimited kindness which means that $\mathrm{He}$ is unable to do anything unkind. The human being cannot fully become like to the God. But in his/her possession is trying to strengthen his/her will, to become wiser and kinder as much as possible. And this purpose is achievable only for philosophers, the best representatives of mankind, who care about their souls all the time.

The philosopher is the perfect human being ("mard") who has similarities with the God in the three above mentioned features. The God is omnipotent and $\mathrm{He}$ can do and $\mathrm{He}$ does whatever He whishes. The perfect man also can do whatever $\mathrm{s} / \mathrm{he}$ wishes as the human, because s/he never aspires to do that which is impossible for him/her to do. David says that unfulfilled wishes cause a big sadness. This statement is very actual for contemporary situation of the human being. Peace in the soul and happiness nowadays are rare not because the conditions of life are difficult, but because today's people want more and are not satisfied. We don't think on limitation of our desires. But this is the way to become like to the God, according to David. In Armenian the word "Definition" ("sahmanq") also means limitation and David the Invincible says that philosophers are thinking about limits, borders that human's desires must have.

The God is kind or good, because $\mathrm{He}$ cares for humans and desires all of mankind's welfare. Indeed, goodness is God's essence. According to David goodness is not human's primary essence; rather, a human being acquires goodness. Armenian thinker explains this contrast metaphorically, as follows: God's goodness is similar to the sun, which can not co-exist with darkness (evil); whereas man's capacity for goodness is similar to the air, which receives light when the sun rises and stayed in darkness when the sun sets. So the purpose of philosophy is cultivation of the light of kindness.

The God is omniscient: He knows all and at all times. The human also aspires to omniscience, but his comprehension is dictated by possibility and not reality, because he knows different things at different times (David The Invincible, $1980^{\mathrm{b}}$, p. 69). The human acquires wisdom, which is unity of the theoretical and the practical. The wise man is not the one who knows many things and is able to speak about them; wise man is the one who lives life full of goodness and virtues. The God cares about the existing world because of his wisdom, and if wisdom exists so does philosophy; hence human's ability to resemble the God is granted to him through philosophy.

The human is the most important actor in David's philosophical system as a formulator of the "cosmos", because even the God needs the existence of the Human being. The human being exists for appreciation of the God's creation and for attempt to create similar order in the own world. The philosopher as the perfect human being is forming/ improving his/her soul and helping others to care about them- 
selves in order to be able to see the God's light of kindness. Forming ("zardarel") can be understood in other meaning also. David says that the God needs a human being as a creature that will appreciate God's creative endeavor. Here David's thinking is not merely medieval, it is evidently actual for us, and because he says that a human being is the one that can form ("zardarel") not only his /her self but also the whole Universe. This means that the human being is giving the meaning to the whole existence, and philosophy is the sphere of signification, and the care of the soul is bringing meaning to this life. So people who like this love of wisdom live in a meaningful reality and feel the wholeness of the life.

This is why David was highly appreciated by his students and followers. Although for some religious or ideological reasons silence surrounded the name of David in the VI-VII centuries, the titles of his lectures maintain the signs of the highest appreciation of the thinker. David's Greek texts preserved his titles "theophilestatos kai theofron", that is "the most loving the God and godly-minded" (Busse, 1904). A. Muradyan noticed that some Armenian manuscripts also contain the mentioned titles (Muradyan, 1981, p. 198). Contemporary researchers in contrast to the Armenian historical tradition consider David as "a figure of minor importance" (Barnes, 2009, p. 14) or as one of the last representatives of the Alexandrian school of Neoplatonism (Sorabji, 1990, pp. 29-30). Trying to understand this mismatch of the approaches and for comparative purposes I looked at the volumes of CAG, containing the works of the well noun philosophers of the time to see if they also bear such titles as David does. We can see that the titles "the most loving the God and godly-minded" are attributed only to David, while the leader of the Alexandrian school Ammonius in the commentary of the "Categories" just is called a philosopher (CAG IV , 4: 1), and in the commentary of Porphyry's Isagoge is called the son of Hermeias (CAG IV, 3: 1), Olympiodorus is also called a philosopher (CAG XVIII, 1:1), Dexippus is called a platonian philosopher (CAG IV, 2: 2) and Simplicius's name merely is written on the title of his commentary on Aristotle's "On the Soul" without any epithet (CAG, XI: 1). Not having an opportunity to look at all the volumes of the CAG, just from the mentioned above examples we can understand that David the invincible earned a highest respect from his followers. He was called not merely "theophilos" - a lover of the God, but in the superlative degree - "Theophilestatos" - the person who loves the God more than anyone. Comparing the works of David and Ammonius we see the same six definitions of philosophy and the main approach to philosophy as a likelinees to God, but why Ammonius, the head of the school, is not called "theophilos"? Question is remaining open. Instead, David is called not anly "theophilos", but also "theophron", which means "having divine mind, godly-minded, holy" (Dworetski, 1958), (Liddel \& Scott, 1968). These epithets are mentioning the importance of David thinker and present him as a former of a tradition not just merely as one of the last followers. Of course, there are many uncertainties concerning David's lifetime, heritage and view-points, but the fact he was highly appreciated in the Greek philosophical cycles cannot be denied. 


\section{REFERENCES}

Araqel Sjunetsi. (1797). Luc'munq Yaghags Sahmanacs Dawt'i Anyaght' P'ilisop'ayi, Girq Sahmanac srboyn Dawt'i Anyaght' P'ilisop'ayi Hayoc imastasiri (Commentaria on David the Invincible's Definitions of Philosophy. Definitions of Philosophy by David the Invincible, Holy Philosoph of Armenians, in Armenian). Madras.

Barnes, J. (2009). David and the Greek Tradition. In V. Calzolari, \& J. Barnes (Eds.). L'oeuvre de David L'Invincible et la transmission de la pensee grecque dans la tradition armenienne et syriaque, Commentaria in Aristotelem Armeniaca- Davidis Opera. Vol. 1. Boston: Brill, Leiden.

Busse, A. (Ed.). (1904). Commentaria in Aristotelem Graeca. Vol. 18, part 2. Berlin.

David Anhaght (the Invincible). $\left(1980^{\text {a }}\right) . \mathrm{Er}$ kasirut'iwnq p'ilisop'ayakanq, hamahavaq qnnakan bnagrery' \& ar'ajabany' S.S. Arevshatyani (Philosophical Tractats, Critical Texts and Introduction by S.S. Arevshatyan, in Armenian). Yerevan.

David Anhaght (the Invincible). (1980'b). Erker, t'argmanut'yuny', ar'ajabany' ev c'anot'agrut'yunnery' S.S. Arevshatyani (Works, Translation, Introdaction and Notes by S.S. Arevshatyan, in Armenian). Yerevan.

Dvoretskii, I. X. (1958). Drevnegrecheskorusskii slovar' (An Old Greek-Russian Dictionary, in Russian). Vol. 1. Moscow.
Foucault, M. (1986). The Use of Pleasure, (R. Harley, Trans.) New York: Pantheon. Foucault, M. (2007). Germenevtika sub'ekta (The Hermeneutics of the Subject, in Russian). The Course of Lectures taught in the College de France in 1981-1982 (Trans. from French). $\mathrm{SPb}$.

Hadot, P. (1995). Philosophy as a Way of Life. In A.I. Davidson (Ed.), Spiritual Exercises from Socrates to Foucault (M. Chase, Trans.). Oxford, Cambridge.

Liddel, H.G., \& Scott, R. (1968). A GreekEnglish Lexicon. Oxford: Clarendon Press.

Muradyan, A. (1981). Davit' Anhaght'i andznavorut'yan, jhamanaki u gitakan jhar'angut'yan harci shurj, (Concerning the Person, the Time and the Scientific Heritage of David the Invincible, in Armenian), Patma-banasirakan handes. No 1.

Petrosyan, S.S. (2000). Davit' Anhaght': P'ilisop 'ayut'yuny' vorpes hogu xnamq (David the Invincible: Philosophy as the Care of the Soul, in Armenian). Newsletter of the Yerevan State University. No 1. Yerevan.

Sanjian, A.K. (1986). David Anhaght (the Invincible): An Introduction. In A.K. Sanjian (Ed.), David Anhaght the "Invincible" philosopher. Atlanta, Georgia: Scholars Press.

Sorabji, R. (1990). The Ancient Commentators on Aristotle. In Sorabji R. (Ed.), Aristotle Transformed, The Ancient Commentators and their influence. Ithaca, New York: Cornell University Press. 